\title{
PRESCRIBING TRENDS IN ASTHMA IN PEDIATRICS: A LONGITUDINAL, OBSERVATIONAL STUDY
}

\author{
AMANPREET KAUR ${ }^{1}$, ARSHIYA SEHGAL ${ }^{1}$, VIJAY K SEHGAL ${ }^{1}$, HARJINDER SINGH ${ }^{2 *}$ \\ ${ }^{1}$ Department of Pharmacology, Government Medical College and Rajindra Hospital, Patiala, Punjab, India. ${ }^{2}$ Department of Pediatrics, \\ Government Medical College and Rajindra Hospital, Patiala, Punjab. India. Email: harjinder427@yahoo.com
}

Received: 27 January 2021, Revised and Accepted: 18 March 2021

\section{ABSTRACT}

Objectives: In recent years, the prevalence of asthma has globally increased. Despite intensive treatment, many children with asthma are not achieving good symptom control. The present study aims to analyze the prescribing trends in pediatric asthma according to the World Health Organization (WHO) prescribing indicators.

Methods: This was an observational, longitudinal study conducted for the duration of 6 months with a sample size of 62 . Children with age 1-14 years with asthma, who fulfilled the inclusion criteria, were enrolled after obtaining the written informed consent. Data were collected from outpatient department prescription slips for 2 times, one at $1^{\text {st }}$ enrollment and the next after 1 month and changes in the prescription were noted. Peak expiratory flow rate (PEFR) was measured on both visits and the change in PEFR was noted.

Results: Male predominance was seen (67.74\%) with age of 5-9 years (40.32\%). Average number of drugs per prescription was 1.96 . The most commonly prescribed anti-asthmatic drug was inhaled corticosteroids (ICS) (78.22\%). Only 1.5\% drugs were prescribed by generic names and $22.22 \%$ drugs from the essential drug list. Inhalational route (38.71\%) was preferred over the oral route (20.97\%). After 1 month of treatment, change in PEFR was found to be statistically significant.

Conclusion: The study concluded that average number of drugs per prescription and use of antibiotics was conforming to the WHO prescribing standards but prescribing from essential medicines list and by generic name need to be encouraged.

Keywords: Pediatrics, Asthma, Prescription.

(C) 2021 The Authors. Published by Innovare Academic Sciences Pvt Ltd. This is an open access article under the CC BY license (http://creativecommons.org/ licenses/by/4.0/) DOI: http://dx.doi.org/10.22159/ajpcr.2021v14i5.40894. Journal homepage: https://innovareacademics.in/journals/index.php/ajpcr

\section{INTRODUCTION}

Asthma is a common chronic disease in children, striking a constant burden on the health system. In current years, the prevalence of asthma has increased globally in children and adolescents, particularly in lowmiddle income countries [1]. It is characterized by recurrent reversible airway obstruction in response to irritant stimuli that are too weak to affect non-asthmatic subjects [2]. According to the Global Asthma report 2018 , the prevalence of asthma is $<5 \%$ in the Indian subcontinent [3], yet it imposes a significant clinical burden in a state like Punjab due to increased environmental pollution, especially in months of April-May and October-November due to stubble (paddy remains) burning in the fields.

Inflammation of airways, reversible airway obstruction, and bronchial hyper-reactivity are the characteristic features of asthma. In asthma, prolonged, pathogenic inflammation, and abnormal repair of injured airway tissues can be stimulated as a result of immune response to common airway exposures (e.g., allergens, respiratory viruses, and air pollutants) in the susceptible host [4]. Lung dysfunction and airway remodeling may develop. These pathogenic processes unfavorably affect the growth and differentiation of airways in the growing lung during early life leading to altered airways at mature ages. Even though the cause of childhood asthma has not been determined clearly, a combination of environmental factors and inherent biological and genetic susceptibilities has been drawn in [5].

Diagnosis of asthma is mainly clinical which includes at least three reversible episodes of wheezing. Pulmonary function test with spirometer is the gold standard for diagnosis. There is a decrease peak expiratory flow rate (PEFR), decreased forced vital capacity, deceased forced expiratory volume (FEV1), and decreased forced expiratory flow (FEF) at 25-75\% (FEF25 $\rightarrow$ FEF75).

Asthma management is aimed at reducing airway inflammation and controlling comorbid conditions that can worsen asthma. The longterm goal of asthma management is the achievement of optimal asthma control.

Significant morbidity and mortality are caused by asthma worldwide and there is minimal improvement in vital outcomes over the last decade in spite of increasing treatment cost [6]. Studies have shown that management of asthma in children is short of goals because many physicians fail to adhere to asthma guidelines in diagnostic approach and treatment [7].

There is a scarcity of Indian data in the evaluation of prescription patterns in bronchial asthma. Hence, this study was designed to assess the prescription trends of bronchial asthma patients by the World Health Organization (WHO) Prescribing Indicators at a tertiary care hospital in Punjab and to determine the areas which require further research.

\section{METHODS}

\section{Study design}

This was an observational and longitudinal study with a follow-up of 1 month.

Study site

This study was outdoor patient department (OPD) of the Department of Paediatrics, Government Medical College and Rajindra Hospital, Patiala. 


\section{Study duration}

This study was carried over a period of 6 months after the approval from the Institutional Ethics Committee and the Clinical trials registryIndia.

\section{Sample size}

A total of 62 patients were enrolled.

\section{Inclusion criteria}

The following criteria were included in the study:

1. Children with age 1-14 years.

2. Presence of wheeze, with a history of more than 4 episodes of documented wheeze, or use of bronchodilators in preceding 12 months.

\section{Exclusion criteria}

The following criteria were excluded from the study:

1. Children having any other respiratory disease or with the alternative cause of recurrent wheezing.

\section{Ethical approval}

Prior approval from Institutional Ethics Committee and Clinical Trials registry-India with CTRI Number - CTRI/2019/10/021739 was obtained.

\section{Study procedure and data collection}

Patients attending the pediatrics outdoor department were screened according to inclusion/exclusion criteria. Patients eligible for the study were enrolled after explaining the aim of the study to the patients and parents of the patients. Written informed consent and assent were obtained from each patient/parent of the patient.

Data were collected in the form of OPD prescription slips 2 times, one at $1^{\text {st }}$ enrollment of the patient and then after 1 month from the first enrollment, and by direct conversation with the patient and parents of the patient. Change in PEFR was checked with a peak flow meter

\section{PEFR}

PEFR was recorded with peak flow meter, during $1^{\text {st }}$ visit and after 1 month of treatment and difference was noted. During each visit, 3 readings of PEFR were taken and the maximum value was picked up. The same peak flow meter was used every time to minimize the error.

\section{Statistical analysis}

Descriptive analysis was done. IBM SPSS version 22 was used. Qualitative data were measured as frequency and percentage. Quantitative data were measured as mean, median, and standard deviation. Change in PEFR was evaluated with the Pearson Chi-square test. $\mathrm{p}<0.05$ was considered significant.

\section{RESULTS}

Out of a total of 62 children enrolled in the study, male patients $(67.74 \%)$ were more than female patients (32.26\%). Maximum patients $(40.32 \%)$ were in age between 5 and 9 years, followed by $30.65 \%$ with age between 10 and 14 years. Mean age was 8.60 (3.37), as shown in Table1.

Prescriptions were analyzed according to WHO Prescribing indicators, as shown in Table 2. Average number of drugs prescribed per prescription was 1.96. Antibiotics were prescribed in 07 (11.79\%) patients. Cefpodoxime was the most commonly prescribed antibiotic $(8.06 \%)$ followed by cefixime and azithromycin (1.61\% each). Injectables were not prescribed in any patient. Only $1.5 \%$ drugs were prescribed by generic name and $22.22 \%$ drugs were prescribed from the essential drug list.

The most commonly prescribed anti-asthmatic drugs were ICS such as fluticasone propionate (58.05\%) and budesonide (20.17\%). Long-acting beta-2 agonists (LABA) such as salmeterol (54.83\%) and formoterol $(3.22 \%)$ were used in combination with fluticasone propionate. Leukotriene receptor antagonist (LTRA) like montelukast was prescribed in $47.58 \%$ children and short-acting beta- 2 agonists (SABA) such as salbutamol (20.40\%) and levosalbutamol (15.08\%) were prescribed in $35.48 \%$ children. Oral steroids (OS) were prescribed in $4.48 \%$ children. The prescriptions of ICS, OS, LABA, and LTRA were increased on visit 2 (follow up after 1 month) but there was a decrease in the prescription of SABA on follow up as shown in Fig. 1

Combinations therapy was used in $79.03 \%$ children. The most commonly prescribed fixed-dose combination (FDC) was that of ICS+LABA (Fluticasone propionate+Salmeterol) (54.83\%) and Fluticasone+Formoterol (3.22\%). Montelukast+Levocetirizine combination was used in $20.96 \%$ children, as shown in Table 3.

As shown in Fig. 2, 24.19\% patients were treated with monotherapy and $75.80 \%$ patients with polytherapy (>one anti-asthmatic drug). Three drug therapy was most commonly used $(35.48 \%)$ followed by two drug therapy (32.25\%).

Most patients were prescribed with both oral and inhalational route (40.32\%) followed by inhalational alone (38.71\%) and oral alone (20.97\%).

It was observed that mean PEFR in children of 0-5 years age group was $140 \mathrm{~L} / \mathrm{min}$, in 6-11 years, age group was $202.20 \mathrm{~L} / \mathrm{min}$ and in 12-14 years was $277.37 \mathrm{~L} / \mathrm{min}$, and this difference was found to be statistically significant.

Table 1: Baseline characteristics of the study population

\begin{tabular}{lll}
\hline Characteristics & Patients (n) & Percentage \\
\hline Gender & & \\
Female & 20 & 32.26 \\
Male & 42 & 67.74 \\
Age (years) & & \\
$0-4$ & 18 & 29.03 \\
$5-9$ & 25 & 40.32 \\
$10-14$ & 19 & 30.65 \\
Total & 62 & 100 \\
Mean \pm SD & $8.60 \pm 3.37$ & \\
Median & 8.00 & \\
Range & $3-14$ & \\
\hline
\end{tabular}

Table 2: WHO prescribing indicators

\begin{tabular}{llll}
\hline S. No. & Name of the indicator & $\begin{array}{l}\text { Result } \\
\text { (\%) }\end{array}$ & $\begin{array}{l}\text { Optimal } \\
\text { value (\%) }\end{array}$ \\
\hline 1. & $\begin{array}{l}\text { Average number of drugs per } \\
\text { prescription }\end{array}$ & 1.96 & $1.6-1.8$ \\
$2 . \quad$ & $\begin{array}{l}\text { Percentage of drugs prescribed } \\
\text { by generic name }\end{array}$ & 1.5 & 100 \\
$3 . \quad \begin{array}{l}\text { Percentage of prescriptions } \\
\text { with an antibiotic prescribed }\end{array}$ & 11.79 & $20.0-26.8$ \\
$4 . \quad \begin{array}{l}\text { Percentage of prescriptions } \\
\text { with an injection prescribed }\end{array}$ & 0 & $13.4-24.1$ \\
5 & $\begin{array}{l}\text { Percentage of drugs prescribed } \\
\text { from essential drug list }\end{array}$ & 22.22 & 100 \\
\hline
\end{tabular}

Table 3: Drugs used in combination therapy

\begin{tabular}{llll}
\hline Combination & Drugs & Patients & Percentage \\
\hline ICS+LABA & Fluticasone+Salmeterol & 34 & 54.83 \\
& Fluticasone+Formoterol & 02 & 3.22 \\
LTRA $+\mathrm{H}_{1}$ Receptor & Montelukast+ & 13 & 20.96 \\
Antagonist & Levocetirizine & & \\
Total & & 49 & 79.03 \\
\hline
\end{tabular}

ICS: Inhaled corticosteroids, LABA: Long acting beta- 2 agonists,

LTRA: Leukotriene receptor antagonist 
This shows that in the age group of $0-5$ years, girls have higher PEFR than boys, but in other age groups, boys have higher PEFR than girls, but the difference is statistically insignificant.

PEFR was measured on both visits and change in the value of PEFR was noted. Rise in PEFR was seen in $61.29 \%$ patients, fall in PEFR was seen in $25.81 \%$ patients, and there was no change in PEFR in $12.90 \%$ patients. Maximum rise in PEFR was seen in Age group of $12-14$ years (68.42\%) and maximum fall of PEFR was seen in 6-11 years age group (32\%). Change in PEFR was found to be statistically significant in all age groups.

The PEFR was analyzed according to the treatment given in children. It was seen that ICS and SABA were associated with a rise in PEFR and OS, LABA

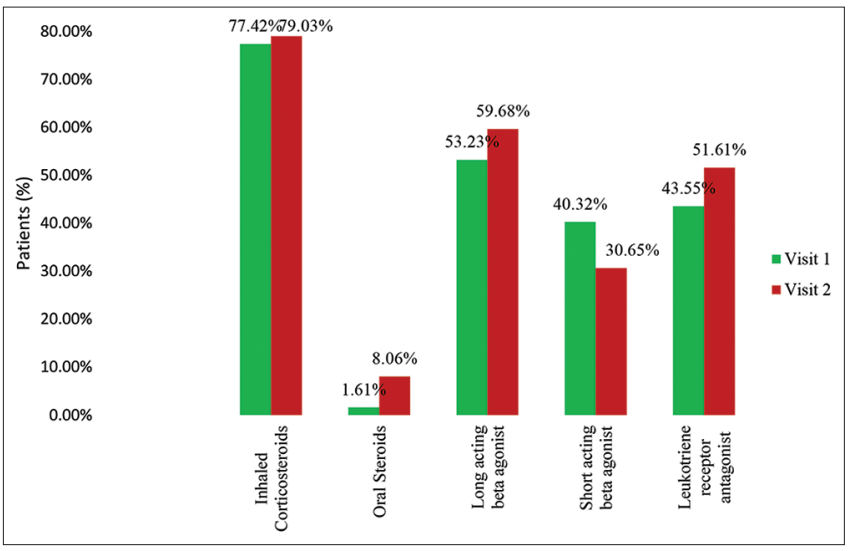

Fig. 1: Percentage of various groups of drugs prescribed in the study population during visit 1 and visit 2

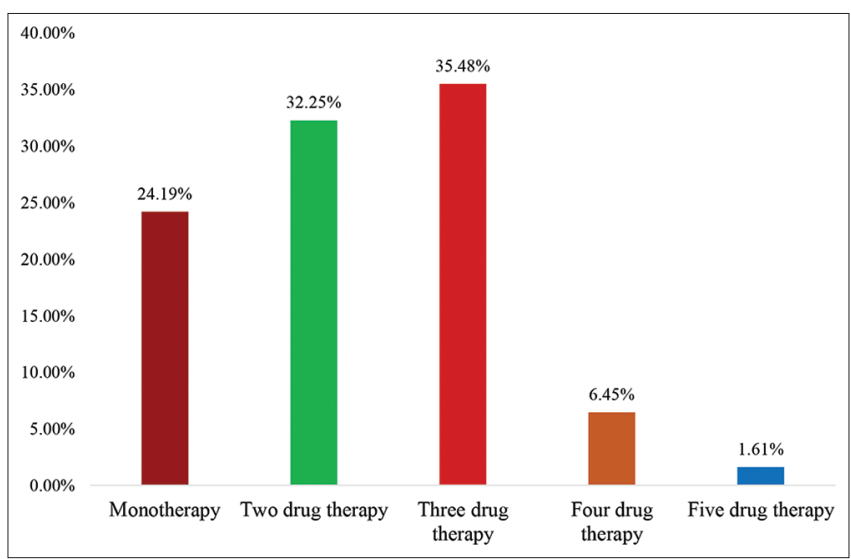

Fig. 2: Distribution of the study population prescribed with monotherapy and polytherapy

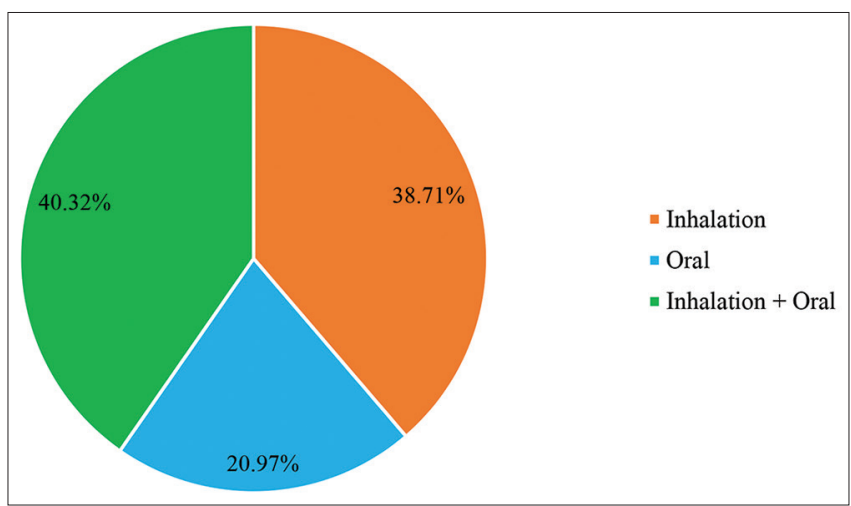

Fig. 3: Routes of drug administration and LTRA were associated with a decrease in PEFR. The observed change in PEFR with respect to drugs used was found to be statistically significant.

\section{DISCUSSION}

In this study, the population of male patients was more than females which were in accordance with a study done by Fuseini and Newcomb [8] which showed that boys have an increased prevalence of asthma compared to girls (11.9\% vs. $7.5 \%$, respectively). Another study conducted by Schatz and Camargo [9] also showed the male predominance over females in pediatric asthma.

Maximum patients were in the age group of 5-9 years. This was in accordance with a study conducted by Kamfar and Koshak [10], which showed that asthma prevalence and severity increase in children in school-going age.

ICS were most commonly used (fluticasone propionate more than budesonide). OS were used in $9.6 \%$ of patients which is in accordance with a study done by Gupta et al. [11], in which the use of systemic steroids was $8.5 \%$. Long-acting beta-agonists were used in 58.06\% patients (salmeterol>formoterol). Short-acting beta-agonists were used in $40.3 \%$ of patients (salbutamol>levosalbutamol) and LTRAs (montelukast) were used in $45.1 \%$ of patients.

Since patients with asthma require more than one drug for the control of symptoms, so combination therapy is required for treatment [12]. Fixed-dose combinations were used in $79.03 \%$ of patients. The most commonly prescribed combination therapy was seroflo inhaler which contains salmeterol and fluticasone propionate. The use of this FDC was in accordance with a study done by Friedman et al. [13], in which the ICS-LABA combination was used in $55 \%$ of patients. Another study done by Thomas et al. [14] reported that combination therapy with ICSLABA therapy was prescribed for $7 \%$ of patients which was quite low as compared to this study. Monotherapy was given in $24.19 \%$ of patients which is slightly higher than the study done in Gorakhpur by Pandey et al. [15] (19\%) but is lower than in a study done by Prasad et al. [16], in which all patients were prescribed with multiple drug therapy.

The most commonly prescribed route was the inhalational route which is contrary to a study done by Pandey et al. [15], which demonstrated that oral dosage form (56.3\%) was preferred over inhalation (33.8\%). Srivastava et al. [17] also reported that oral dosage forms like tablets (54.93\%) were preferred over inhalation (31.69\%).

Table 4: Mean and SD of PEFR according to age

\begin{tabular}{llllll}
\hline Age group & $\begin{array}{l}\text { Number of } \\
\text { patients }\end{array}$ & $\begin{array}{l}\text { Mean PEFR } \\
\text { (L/min) }\end{array}$ & SD & F value & p value \\
\hline 0-5 years & 18 & 140.00 & 23.70 & 57.948 & 0.001 \\
6-11 years & 25 & 202.20 & 34.64 & & \\
12-14 years & 19 & 277.37 & 53.21 & & \\
Total & 62 & 207.18 & 65.88 & & \\
\hline
\end{tabular}

PEFR: Peak expiratory flow rate, SD: Standard deviation

Table 5: Mean and SD of PEFR according to age and sex

\begin{tabular}{|c|c|c|c|c|c|c|c|c|}
\hline \multirow{2}{*}{$\begin{array}{l}\text { Age } \\
\text { group }\end{array}$} & \multicolumn{3}{|l|}{ Boys } & \multicolumn{3}{|l|}{ Girls } & \multirow[t]{2}{*}{ t-test } & \multirow{2}{*}{$\begin{array}{l}p \\
\text { value }\end{array}$} \\
\hline & Total & $\begin{array}{l}\text { Mean } \\
\text { PEFR }\end{array}$ & SD & Total & $\begin{array}{l}\text { Mean } \\
\text { PEFR }\end{array}$ & SD & & \\
\hline $\begin{array}{l}0-5 \\
\text { years }\end{array}$ & 11 & 135.91 & 22.23 & 07 & 146.43 & 26.25 & 0.913 & 0.375 \\
\hline $\begin{array}{l}6-11 \\
\text { years }\end{array}$ & 18 & 207.22 & 29.57 & 07 & 189.29 & 45.32 & 1.171 & 0.253 \\
\hline $\begin{array}{l}12-14 \\
\text { years }\end{array}$ & 13 & 285.77 & 55.67 & 06 & 259.17 & 46.63 & 1.014 & 0.325 \\
\hline Total & 42 & 212.86 & 68.40 & 20 & 195.25 & 60.16 & 0.983 & 0.329 \\
\hline
\end{tabular}


Table 6: Change in PEFR in different age groups of the study population

\begin{tabular}{lllllll}
\hline Age group (years) & Patients(Total) $\mathbf{n}(\%)$ & PEFRIncreased (\%) & PEFRDecreased (\%) & PEFRNo change (\%) & $\boldsymbol{\chi}^{2}$ & p value \\
\hline $0-5$ & $18(29.03)$ & $10(55.56)$ & $04(22.22)$ & $04(22.22)$ & 7.68 & 0.006 \\
$6-11$ & $25(40.32)$ & $15(60)$ & $08(32)$ & $02(8)$ & 17.93 & 0.001 \\
$12-14$ & $19(30.65)$ & $13(68.42)$ & $04(21.05)$ & $02(10.53)$ & 12.19 & 0.001 \\
Total & $62(100)$ & $38(61.29)$ & $16(25.81)$ & $08(12.90)$ & & \\
\hline
\end{tabular}

PEFR: Peak expiratory flow rate

Table 7: Change in PEFR according to various drugs used in the study population

\begin{tabular}{lllllllll}
\hline Change in PEFR & \multirow{2}{*}{ Total (n) } & \multicolumn{2}{c}{ Drugs used } & & \multirow{2}{*}{$\boldsymbol{\chi}^{2}$} & \multirow{2}{*}{ p value } \\
\cline { 2 - 6 } & & ICS (n \%) & OS (\%) & LABA (\%) & SABA (\%) & LTRA (\%) & \\
\hline Increased & 38 & $29(76.32)$ & $01(2.63)$ & $20(52.63)$ & $12(31.58)$ & $21(55.26)$ & 4.39 & 0.036 \\
Decreased & 16 & $11(68.75)$ & $04(25)$ & $11(68.75)$ & $04(25)$ & $10(62.50)$ & 9.01 & 0.003 \\
No Change & 08 & $06(75)$ & $00(0)$ & $03(37.50)$ & $02(25)$ & $01(12.50)$ & 10.08 & 0.002 \\
\hline
\end{tabular}

PEFR: Peak expiratory flow rate, ICS: Inhaled corticosteroids, OS: Oral steroids, LABA: Long-acting beta-2 agonists, SABA: Short-acting beta- 2 agonists,

LTRA: Leukotriene receptor antagonist

The WHO's prescribing indicators are a fastand effective means of assessing potential problems in drug use in healthcare settings [18]. The average number of drugs per prescription was 1.96, which was in accordance with the standard value (1.6-1.8) [19]. A higher value was reported by a study done by Michael et al. (5.95) and Aleemuddin et al. (13.25) [20,21].

The percentage of drugs prescribed by generic name in the present study was very less (1.5\%) as compared to the standard value of $100 \%$. A study done by Olurishe and Mohammed [22] observed that $45.5 \%$ of drugs were prescribed by generic name in asthma which was quite higher as compared to our study. However, it also indicates the availability of generic drugs in the hospital supply, which is often very erratic. The percentage of prescriptions with an antibiotic was $11.79 \%$ which is comparatively less than the study done by Lovinsky and Rastogi [23]. Injectable was not prescribed in any patient. The percentage of drugs prescribed from the essential drug list was $22.22 \%$ which is less as compared to the standard value of $100 \%$. This also reflects the fact that free drug supply in the hospital pharmacy is short, as per EDL.

In the age group of $0-5$ years, girls had higher PEFR than boys, but in other age groups (5-9 years, 10-14 years), boys had higher PEFR than girls, but the difference was statistically insignificant. A study conducted by Shiyas and Gopi [24] found that boys had significantly higher PEFR than girls in age 11 and 12 years, while in age 9 and 10 years, it was statistically insignificant.

\section{CONCLUSION}

Our study concluded that prescribing pattern of anti-asthmatic drugs in our setting does not completely conform to WHO prescribing indicators. The most commonly prescribed drug in children with asthma was ICS (fluticasone propionate). Combination therapy was preferred over monotherapy. The most commonly prescribed route was the inhalational route. Most drugs were prescribed by brand name, so we have not been able to achieve the prescribed standards in prescription with generic names and prescriptions from the essential drug list. The study underlines that there is scope for improvement in this field as a prescription by brand name increases the cost of the treatment and economic burden to the patient.

\section{ACKNOWLEDGMENT}

We are thankful to our guide Dr. Vijay K Sehgal, for his guidance, Dr. Harjinder Singh for helping in patients' enrollment, and our patients and their parents who gave consent to participate in the study.

\section{AUTHORS' CONTRIBUTIONS}

We thank all the authors for their help at various levels in the smooth conduction of this research work, data collection, and preparation of the manuscript.

\section{CONFLICTS OF INTEREST}

None.

\section{AUTHORS' FUNDING}

None.

\section{REFERENCES}

1. Ferrante G, La Grutta S. The burden of pediatric asthma. Front Pediatr 2018;6:186.

2. Sharma HL, Sharma KK. Principles of Pharmacology. $3^{\text {rd }}$ ed. New Delhi: Paras Medical Publisher; 2017.

3. The Global Asthma Report, Auckland, New Zealand; 2018. Available from: http://www.globalasthmareport.org. [Last assessed on $2021 \mathrm{Feb} 25]$.

4. Kleigman RM, Jeme JW, Blum NJ, Shah SS, Tasker RC, Wilson KM, et al. Nelson Textbook of Paediatrics. In: Liu AH, Spahn JD, Sicherer SH, editors. Childhood Asthma. $21^{\text {st }}$ ed. Canada: Elsevier; 2019. p. 4945-9.

5. Burbank AJ, Sood AK, Kesic MJ, Peden DB, Hernandez ML. Environmental determinants of allergy and asthma in early life. $\mathrm{J}$ Allergy Clin Immunol 2017;140:1-12.

6. Gupta A, Bhat G, Pianosi P. What is new in the management of childhood asthma? Indian J Pediatr 2018;85:773-81.

7. Klok T, Kaptein AA, Brand PL. Non-adherence in children with asthma reviewed: The need for improvement of asthma care and medical education. Pediatr Allergy Immunol 2015;26:197-205.

8. Fuseini $\mathrm{H}, \mathrm{Newcomb}$ DC. Mechanisms driving gender differences in asthma. Curr Allergy Asthma Rep 2017;17:19.

9. Schatz M, Camargo CA Jr. The relationship of sex to asthma prevalence, health care utilization, and medications in a large managed care organization. Ann Allergy Asthma Immunol 2003;91:553-8.

10. Kamfar HZ, Koshak EE. The impact of some demographic factors on the severity of asthma in children. J Family Community Med 2002;9:19-24

11. Gupta S, Awasthi S. Assessment of treatment pattern of childhood asthma reporting to outpatient's facility in a tertiary care hospital in Lucknow, North India: A cross-sectional study. Clin Epidemiol Glob 2016;6-11

12. Shah RD, Burute SR, Ramanand SJ, Murthy MB, Shah ND, Kumbhar AV. Drug utilization study in patients with bronchial asthma of a tertiary care hospital in Western Maharashtra. Indian J Allergy Asthma Immunol 2019;33:105-11.

13. Friedman HS, Eid NS, Crespi S, Wilcox TK, Reardon G. Retrospective claims study of fluticasone propionate/salmeterol fixed-dose combination use as initial asthma controller therapy in children despite guideline recommendations. Clin Ther 2009;31:1056-63.

14. Thomas M, Murray-Thomas T, Fan T, Williams T, Taylor S. Prescribing patterns of asthma controller therapy for children in UK primary care: A cross-sectional observational study. BMC Pulm Med 2010;10:29.

15. Pandey A, Tripathi P, Pandey RD. Prescription pattern in asthma therapy at Gorakhpur hospitals. Lung India 2010;27:8-10.

16. Prasad A, Pradhan SP, Datta PP, Samajdar SS, Panda P. Drug prescription pattern for bronchial asthma in a tertiary-care hospital in 
Eastern India. Natl J Physiol Pharm Pharmacol 2015;5:263-6.

17. Srivastava R, Sharma S, Keshri L, Wal P. Assessment of prescription pattern in asthma therapy at Shamli hospitals. Rev Recent Clin Trials 2012;7:158-64.

18. World Health Organization. Introduction to Drug Utilization Research. Geneva: World Health Organization; 2003. Available from: https:// www.apps.who.int/medicinedocs/pdf/s4876e/s4876e.pdf.

19. International Network for Rational Use of Drugs. The Development of Standard Values for the WHO Drug Use Prescribing Indicators. Geneva: World Health Organization; 2004. Available from: http://www.

archives.who.int/prduc2004/rducd/ICIUM Posters/1a2 txt.htm

20. Michael B, James N, Sreena S, Sindhuja K, Nanjwade BK. Drug utilization evaluation of bronchial asthma in tertiary care hospital.
World J Pharm Pharm Sci 2016;5:1075-91.

21. Aleemuddin NM, Bahmed F, Bashir MS, Ali A, Khatoon S, Hussain MM, et al. A cross-sectional study on prescribing patterns on patients suffering from respiratory disorders in a teaching hospital of South India. J Contemp Med Dent 2014;2:12-7.

22. Olurishe $\mathrm{CO}$, Mohammed M. Evaluation of steroid utilization in management of asthma in a tertiary hospital in Northern Nigeria. Afr J Pharmacol Ther 2015;4:33-9.

23. Lovinsky S, Rastogi D. Prescription habits for preventative medications among pediatric emergency department physicians at an inner-city teaching hospital. J Asthma 2010;47:1011-4.

24. Shiyas KP, Gopi M. Factors affecting peak expiratory flow rates in children of 9-12 years of age. Int J Pediatr Res 2017;4:651-56. 